\title{
Higher Education in India: Quantity Vs Quality
}

\author{
Dr. Anuradha Goswami*
}

\begin{abstract}
Education is one of the Potential elements in the human kind. It is probably the fourth need after three basic needs viz. food, clothing and shelter. It is an essential human virtue. "Education", more education, education made perfect is the only panacea for our country's ills and evils. Through centuries, education has been a very potent tool for human kind in facing challenges and furthering progress. Education is reorganized as one of the critical elements of the national development efforts and higher education, in particular, is of vital important for the nation, as it is a powerful tool to build knowledge based society of the $21^{\text {st }}$ century.
\end{abstract}

\section{INTRODUCTION}

In our national development process, education system has a very important role to play, specially the Higher Education. After independence, we wanted to build a modern, strong, dynamic and self-reliant India which could stand abreast with the developed nations. Education in general and higher education in particular is the strongest instrument for the development and humanization of mankind. Higher education is a very important sector for the growth and development of human resource which can take responsibility for social, economic and scientific development of the country. Higher education is recognized as a vehicle for sustainable development and is realized as a powerful tool to build knowledge based society. Higher education creates professionals, thinkers, future teachers, researchers, economist and knowledge workers, who, besides inhabiting knowledge societies, can be instrumental in creating them.

Higher education sector has witnessed a tremendous increase in its institutional capacities in the years since independence. The increase in the number of higher education institutions in recent times has brought in a positive change in our social fabrics but it has also put a premium on quality assurance. In accord with the changing perceptions there is a possibility of every institutions being subjected to mandatory accreditation in place of present voluntary submission for scrutiny. In such a scenario quality assurance becomes the watchword in every institutions and the need for maintaining healthy practices will be felt more.

After independence, we wanted to build a modern, strong, dynamic and self-reliant India which could stand abreast with the developed nations while working towards recent, the country has been facing a number of challenges and there are various issues that stand before the system of Higher Education.

\section{Higher Education In India - Issues And Challenges}

Although higher education has expanded several times since independence, issues of access, equity and quality still continued to be the areas of concern. New developments in science and technology, media, revolution, the trend of Internationalization and the ever expanding competitive environment are revolutionizing Higher education scenario. The challenge is to produce skilled manpower with adequate knowledge and skill to effectively confront the existing social and economic realities of today. Some broad issues are like knowledge economy, complexity of Indian Federalism (Central -state relations), political and legal inertia, politicization of policy communication and implementation, funding, privatization, quality assurance, organizational cultures, internationalization of higher education.

The role of higher education institutions in this emerging scenario of knowledge economy is very crucial and multifaceted. The agenda of higher education institutions (universities) in this scenario may include opening new vistas of learning, new frontiers of researching, academic restructuring, sharing of expertise, innovation, technology transfer, knowledge management, training, employability, entrepreneurship, media convergence and meeting social, cultural and economic challenges thrown by the forces of globalization. Issues like access, equity, inclusion, quality and excellence are very complex and intertwined with political, economical, demographic and international dimensions.

Thus it is high time India recognizes the importance of reforms in higher education which is the key to the realization of the vision of the inclusive society and vibrant democracy. 


\section{India's Concerns: Quantity V/S Quality}

Quantity in higher education is another burning issue, which can be ensured through regular review of the function of the institutions either through self assessment or through outside agencies and by accrediting the institutions. The expansion of higher education over the years has also resulted in educational malpractices, which exist in the form of capitation fees being charged by private institutions at the time of admissions, in addition to the fees and various other charges imposed upon the students. The entry of large number of private institutions has also resulted in rapid proliferation in litigation involving students, teachers, employees, management of higher educational institutions and universities and other stake holders. In the absence of a speedy, justice delivery system for resolution of disputes, dissatisfaction among stakeholders adversely impacts the quality of education and efficient function of the institutions.

The quality in higher education is the biggest need of the hour as our country is progressing towards becoming the educational hub of the world. For a nation to economically sustained progress it must continuously replace its aging and perhaps obsolete manpower with high skilled, trained and knowledgeable worker, engineers, doctors, and technicians. There are many examples of the great nation suffering from shortage of skilled manpower (China, France, Philippines, etc.) However, recognized professors should be retained even after their retirement as Professor Emeritus or as Adjunct Professors to have their best for the promotion research activities.

\section{Recommendations}

A multiple policy measures have to be adopted to restructure our existing higher education setup. One important step in this regard may be directed towards reforming education at the primary, secondary and college level, which served as the feeding sources of higher education. The quality in higher education can be improved by formalizing a set of standard processes, developing and using well accepted learning resources, encouraging teachers to learn tools and methodologies, using sound evaluation schemes, continuous feedback evaluation and providing rich and healthy environment. A special attention is to be given in the concepts which require deep understanding, for this use of working models and its demonstration is essential.

The use of more audio visual aids further strengthens the learning ability of the students. They should be enough to attend "webinars", virtual classroom lectures which are beneficial and very -cost effective. For this interconnection of colleges and institutions for knowledge and resource sharing should be encouraged, although this requires the intervention of government bodies and sound policy reforms to form a national "knowledge grid" of various universities and institutions across the country.

Further the admission and evaluation processes should also be scrutinized for betterment so that the admission process filters the most eligible candidates. The candidates who are capable of handling pressure of higher studies. The evaluation process needs to be flexible and modifiable so that it can cater many eventualities associated with students like illness, accidents, social and family problems. To make the best, these young minds need to be provided opportunities for accessing quality higher education. Only quality human resource will ensure emergence of a true knowledge which will ultimately enhance the country's competitiveness in the global economy. Proper steps must be formulated so that inclusion is not done at the cost of academic standard.

\section{Conclusions}

The call of the day, is therefore, is to consolidate our collective experience, vision and vigor or arrive at meaningful and tangle ways to bring Indian education at par with the global standards and make quality adept itself at change. Sharing of regional experiences and replicating the best practices that have worked in one institution is another approach which needs to be discussed and propagated. It is time for all right-minded people - politicians, bureaucrats, academicians, judiciary and entrepreneur - to think as to how to create and enabling environment for large investments for the growth of higher education through policy interventions. In order to realize this we have to consolidate all the efforts made in the field of higher education with an aim to achieve underlying aims of the recommendations of all the committees and commissions set up so far. 


\section{REFERENCES}

[1]. Akhtar, S.W., Quality in Higher Education at Par with International Standards, University News, 49(52), December 26, 2011-01 January, 2012.

[2]. Bhattacharya, Joyati, Higher Education in India: Issues, Concerns and Remedies, University News 50 (17), April 23 -29, 2012.

[3]. Chaturvedi, Lakshman (2012), Consolidation of Higher Education Institutions for quality, University News, Vol. 50, No. 43, Oct. 22-28, 2012.

[4]. Chauhan, C.P.S., (2002), Higher Education in India, Challenges of Global Trends, Aligarh Muslim University, Aligarh. University News, 40(17), April 14-20.

[5]. Goswami, Anuradha (2008), Factorization of Personality Dispositions of Women Distant Learners of J\&K State.

[6]. Jayanti S. Ravi \& H.J. Jani (2012), Roadmaps for Consolidation of Higher Education Institutes for Quality, University News, Vol. 50 No. 43, October 22-28, 2012.

[7]. Padhi, Sambit Kumar (2011), Issues and Challenges and Reforms in Higher Education for Knowledge Society, University News, 49(26), June 27-July 03, 2011

[8]. Rathnam, B. Venkat (2012), Strengthening a Self-Check Mechanism for Consolidation of Higher Education Institutions for quality, University News, Vol. 50 No. 43, October 22-28, 2012.

[9]. Singh, Meenu (2012), Higher Education: Challenges in New Era, University News, 50(39), September 24-30, 2012.

[10]. Srivasthav, Manjulika (2012), Open Universities in India: An Overview for Consolidation, University News, Vol. 50 No. 43, October 22-28, 2012. 